\title{
Vocabularies of Citizenship: West Coast Secondary Students Describe Their Civic Subjectivities, Skills, and Classrooms
}

\author{
Jamie Elbert \\ University of Victoria \\ jelbert@uvic.ca
}

\begin{abstract}
Canada's changing geopolitical landscape will require a generation of engaged and active citizens. Citizenship education in British Columbia must negotiate conflicting narratives while opening spaces for students to develop civic skills and subjectivities. Given negative program reviews, empirical evidence for the impact of identity - especially group identifications - on behaviours and beliefs, and continued low youth political engagement, there is a great need to understand how citizenship and civic subjectivities are constructed in real school contexts in order to gain insight into how secondary civics classrooms might support students' active political voices and development of efficacious subjectivities. This article reports preliminary results from a large mixed methods, multiple-case study project. The data reported here focuses on students $(n=64)$ from two purposefully sampled secondary school classrooms on Vancouver Island: a special civics program, and a regular stream Social Studies classroom in the same school. Data collection consisted of a class-wide online survey near the beginning of the course. Grounded in the larger understandings of social identity theory and rooted cosmopolitanism, qualitative data from open-ended questionnaire responses analyzed with a constant comparative coding technique explored the extent to which students construct regional, national, or global notions of citizenship. A preliminary report of quantitative items investigates the level of conflict present between levels of identification and suggests avenues for future research. Examined against previous research and the theory of rooted cosmopolitanism, this project aims to question the popular narrative of youth apathy and to describe the ways in which students characterize their civic subjectivities. In giving voice to student perspectives on their civic selves and their Civics classrooms, this study aims to contribute to more representative classrooms and pedagogies.
\end{abstract}

\section{Introduction}

The context of Citizenship Education policy and programs in Canada and the world

Citizenship education is a specific program of study, or a theme embedded in other subject domains, that aims to equip students with the knowledge, skills, attitudes, and values essential to an active role in local or global communities (Schulz, Ainley, Fraillon, Kerr, \& Losito, 2010). Citizenship itself is a contested term, but most definitions are accommodated by Gagnon and Pagé's (1999) conceptual framework of four basic components: national identity; cultural, social, and transnational belonging; an effective system of rights; and political and civic participation. In the face of low political engagement and shifting notions of national identity, there is a global trend to nationally-mandated citizenship education programs, especially in nations with high immigration such as Singapore (Ho \& Baildon, 2013), aboriginal and settler populations such as Australia (Macintyre \& Simpson, 2009), and regionalism such as Britain (Hepburn, 2011). Two questions consistently problematize citizenship education Journal of Contemporary Issues in Education, 2017, 12(1), pp. 32-52. 
implementations: What does the term "citizen" actually entail, and what does it mean to be a "good" citizen in a particular context?

Since its creation through Confederation, Canada has used schools as vehicles in the education of good citizens, but provincial control of education has resulted in a wide variety of pedagogy, goals, and outcomes. Despite over 20 years of intense federal, provincial, and scholarly interest, curriculum documents, implementations, and outcomes have garnered tepid to dismal reviews (Evans, 2003; Hughes, Print, \& Sears, 2010; Howe, 2010; Leinweber, Donlevy, Gereluk, Patterson, \& Brar, 2012; McKenzie, 1993). Within the confines of shared provincial guidelines, radically different types of citizenship instruction can occur, shaped by teacher conceptions of good citizenship and resulting in differing student orientations to politics and civic participation (Giron, 2012). In British Columbia, fewer than half of teachers, parents, and students feel the grade 8-12 program serves students' needs and suggest that strong revisions need to be made in content-heavy Social Studies 11 where, incidentally, the majority of civicsrelated material is mandated (BC Ministry of Education, 2007).

Studies of youth in Canada and abroad frequently point to high levels of support for democratic processes and ideals in principle, but extreme cynicism and disengagement in practice (Anderson \& Goodyear-Grant, 2008; Sears, Peck, \& Herriot, 2014). While acknowledging the importance of the electoral process, some suggest that youth are simply engaged in less traditional means than voting and party membership (Dalton, 2008; Martin, 2012), while others argue vehemently that we must guard against inattentiveness to the political world and instead orient students toward traditional norms of political participation (Milner, 2010). Both positive and negative socialization experiences are strong predictors of later political action (Anderson \& Goodyear-Grant, 2008; Kahne \& Sporte, 2008), and so the ubiquitous provincial curricular emphasis on active citizenship is merited. Worldwide, however, large-scale evaluations of the effectiveness of school-based programs is mixed, with some studies noting positive outcomes (Andolina, Jenkins, Zukin, \& Keeter, 2003; Kahne \& Sporte, 2008; Mellor, Kennedy, \& Greenwood, 2002) and others minimizing the school's importance in comparison with individual characteristics and out-of-school factors (Isac, Maslowski, Creemers, \& Van der Werf, 2014; Quintelier, 2015). Canada's increasing role in international conflicts, global climate initiatives, and trade and security agreements should demand the attention and participation of a new generation of citizens; these citizens must feel ready and able to impact decisions made at each level of government as well as in global institutions.

\section{What is a citizen: Conflict in civic subjectivity narratives and a multiplicity of selves}

Modern incarnations of citizenship education must also grapple with the tension between nationalism and cosmopolitanism in a brave new world of multicultural mosaics (see Richardson \& Abbott, 2009). This means negotiating a sensitive milieu of identity politics and avoiding nation-building indoctrination, while opening spaces for students to explore authentic civic subjectivities and practice the real-world civic skills that will help them engage with current political systems. Clearly teaching citizenship is no easy feat. As argued by Myers \& Zaman (2009), many contemporary theories of the nation-state and the subject "oversimplify the complex, and evolving, relationship between national and global dimensions of citizenship" by conceiving of civic subjectivities as fixed rather than socially constructed and contingent ( $\mathrm{p}$. 2589). In addition to tensions between modern meta-narratives, any discussion of identity in post-colonial nations is fraught with conflict. The teaching of history in Canada, for example, has been plagued by passionately unresolved regional and ethnic stalemates (Glassford, 2010; 
Osborne, 2003). Despite the sensitive territory, group identities have nonetheless been examined because of their powerful potential to impact human behaviour and social preferences (Carter, 2013; Charnysh, Lucas, \& Singh, 2015; Chen \& Li, 2009; Benjamin, Choi, \& Strickland, 2010; Hooghe \& Quintelier, 2013), especially as they relate to political identities, opinions, and actions (Ashizawa, 2008; Berdahl \& Raney, 2010; Caron, 2012; Nimijean, 2005; Raney \& Berdahl, 2011; Raney \& Berdahl, 2009). Thus, it is important to investigate the civic subjectivities of Canadians in these changing times as they can impact civic attitudes and actions.

People may define themselves according to multiple subjectivities within the realm of their civic identity; Canadians are said to have "multiple or limited or regional identities" or "to shun even the idea of identity itself...implying a faceless commonality in a postmodernist age of radical variation and pluralism" (Bliss, 2005, p 4). Social psychology underscores the relevance of subjective constructions of self, and social identity theory in particular emphasizes the role of salience in mediating the impact of group identity (Tajfel \& Turner, 1979). Large-scale research on the interaction between in-group criteria and conceptions of nationalism reveal complex links between subjective models of national membership and attitudes such as xenophobia, liberal practices, or acceptance of citizenship norms (Ariely, 2011; Raney \& Berdahl, 2009).

Unsurprisingly, feelings of national attachment in Canada and definitions of "true Canadian" are complicated. Building upon the complexity of nationalism's general implications, studies in Canada point to a weak federal culture, and a strong attachment to regions over provinces - a further complication in locating where Canadian loyalties lie (Fafard, Rocher, \& Cote, 2010; McGrane \& Berdahl, 2013). In consequence, many define Canada's as a civic focused on shared politics and values - rather than ethnic nationalism (Davidov, 2009; Raney, 2010). In an ethnically diverse mosaic, Canadians, it is said, unite under values of human rights, multiculturalism or interculturalism, universal healthcare, a global worldview and commitment to global institutions, and a foreign policy focused on international policing and peacekeeping (Bliss, 2005; Caron, 2012; Dittmer \& Larsen, 2007; Parkin \& Mendelsohn, 2003).

These more globally oriented commonalities have led others to explain Canadians' ways of knowing themselves as cosmopolitan, or as a model of a post-national society. The idea of a global human community, interdependent and mutually responsible for the well-being of all, can be traced far back through philosophy and literature, but more recently has been re-popularized under the new moniker "rooted cosmopolitanism" by Kwame Anthony Appiah $(1996,2006)$ and further developed by the likes of Will Kymlicka and Kathryn Walker (2012). Cosmopolitanism itself is best thought of in categories: institutional and moral, implying the concept of a world state or the ideal that all persons are given equal respect; as a personal identity versus a responsibility, which propose the irrelevance of culture for identity and the irrelevance of national boundaries for the scope of justice; extreme and moderate, where all values are to be derived from cosmopolitan principles, or where special obligations may also justify values; and finally weak versus strong, which dictate either a moral commitment to a minimally or exceeding adequate level of life for all humans (Tan, 2012). These categorizations point to some of the difficulties in defining a political or moral theory of global humanity that receives people as they are, with actual experiences and affinities, rather than the theorist's abstract ideal. Not only is the concept of cosmopolitan still redefining its parameters in the modern era, it can feel overly idealistic or incomplete in the face of anecdotal evidence of patriotism and more extreme xenophobia. Theories such as rooted cosmopolitanism strive to draw together the various national and global strands of modern subjectivities, suggesting that "identities that bind people deeply to their own particular national community and territory can also mobilize moral 
commitment to distant others" (Kymlicka \& Walker, 2012, p. 6). In other words, citizens may feel situated in their particular context and attached or responsible to those in their context, but at the same time ascribe to a global morality, which itself may be motivated by the local or national identifications. This possibility is considered by Brysk (2009), who argues that national citizens acting as global good Samaritans are "not just trying to be better human beings - they take national pride in expressing their [national] identity [...] through these global contributions, and acting globally builds national identities" (p. 221). However, rooted cosmopolitanism, itself a refinement of the universal demands of a cosmopolitan position, is a concept still in flux. The current task of scholars is to define the priority relations between the conflicting aspects of "rootedness" and cosmopolitan universalities. Lenard and Moore (2012) summarize three key streams of current discussion: the instrumental strategy, where particular duties are justified because they "specify who is responsible for discharging general duties with respect to specific others" (p. 51); the constraining strategy, where special duties are acceptable as long as they do not conflict with prioritized cosmopolitan obligations (p. 53); and finally, particularism constrained by deontic duties, where the need for human relationships is itself inherently valuable and, therefore, allowable in a hierarchy of obligations to the extent that it does not conflict with egalitarianism (p. 57). As is evident from a brief summary and indeed as Lenard and Moore (2012) conclude, each attempt to reconcile specific and general attachments or duties is highly problematic; however, as pointed out by Kymlicka and Walker (2012): "we will continue to live in a world where powerful local loyalties and solidarities coexist with the increasingly urgent moral claims of distinct and distant others" (p. 23).

\section{What is good: Educating the modern citizen in Canada}

With regard to civic subjectivities, researchers characterize Canada's approach to education through the 20th century as elitist and passive at best - providing a narrow view of national culture in order to produce a particular type of easily-governed citizen - and "a vehicle of assimilationist nation-building" at worst (Sears, Clarke, \& Hughes, 1999, p. 125; Hodgetts, 1968; Osborne, 1995; Osborne, 1996). Over the course of the century, however, conceptions of citizenship became slowly depoliticized, with an increasing emphasis on personal responsibilities and "character building;" by the mid-2000s every province had reformed its policy and curricula, all moving toward more activist and pluralist orientations (Lewis, 2011; p 169; Evans, 2003; Sears, Clarke, \& Hughes, 1999). More recent critiques of Canadian citizenship curricula argue that neoliberal trends overemphasize the citizen as an economically and globally competitive individual, and the resultant construction of "the active citizen" as a failure (Mitchell, 2003, p. 399; Kennelly \& Llewellyn, 2011).

Since affective identity constructions (such as civic subjectivities) can influence behaviours or be mobilized to elicit certain responses, the role of the nation-state has been examined by scholars, revealing potential for manipulation. Kennelly (2009) argued that Canadian civics curriculum documents emphasize responsibilities over rights, thereby shifting "the burdens of citizenship onto the individual, by continually reiterating the requirement to be self-regulating and self-scrutinizing" (p. 133), and Berdahl and Raney (2010) suggest that "political actors [might] sway Canadian attitudes in specific directions by appealing to various aspects of national identity" (p. 1005). Some argue that modern narratives of multiculturalism are motivated not by ideals of national "unity in diversity" but the competitive economic imperatives of globalization (Mitchell, 2003), or even that a shift toward depoliticized citizenship norms has been encouraged or enforced by governments worldwide as a means of ensuring a 
docile populace to this day (Ho \& Baildon, 2013). Currently, Canada's government-led national narrative is aimed primarily at newcomers and adults and has been criticized for its political agenda (Blake, 2013; Pashby, Ingram, \& Joshee, 2014). Provinces are left to devise regionally appropriate narratives and pedagogies for secondary students; as urged by Levesque (2003), "[t]he key challenge for Canadian educators, then, is not to find a common myth-like grand narrative, which all Canadians can believe deeply, but to build on the inherent differences in their discipline to help 21st century students gain insight and perspectives from other social and cultural contexts" (p. 122).

\section{Research Questions}

The current state of citizenship education as reviewed above has raised two related sets of questions, their interdependence clear in their overlap. As part of a larger project, this paper deals with two foundational questions:

1. What does the term "citizen" actually entail, or, what vocabularies do young Canadians use to construct their civic subjectivities?

2. What does it mean to be a "good" citizen in a particular context and what role might the school play?

This study is interested in how the modern young person constructs him or herself in our globalized and interconnected world, and survey prompts invite student conceptions of citizenship at local, national, and global scales. This study assumes the individual's ability to balance multiple identities rather than requiring one unified and unchanging identity, and so this paper will use the terminology "civic subjectivity" to indicate this flexible and multi-faceted conception of self.

\section{Methodology and Population}

To answer these questions, the full project uses a mixed methods multiple case studies design to describe then compare student perceptions across standard stream Socials 11 and alternative stream civics classes at two public schools. This paper reports findings from the first wave of data collection at one, large middle-income school. To investigate student vocabularies in describing both "citizenship" and "goodness," a collection of open-ended and Likert-scale items on a 30 minute questionnaire explored the concepts of national citizenship, global citizenship, and good citizenship. Some survey items were taken from the established scales used in the International Association for the Evaluation of Educational Achievement's ICCS study (Schulz, Ainley, Fraillon, Kerr, \& Losito, 2010), providing a well-standardized comparison points for this new west-coast Canadian data. These included the distinction between the Conventional Citizenship items and the Social-movement Related Citizenship items, and also provided the Globalized Responsibility items. The distinction between conventional and alternative modes of understanding or expressing citizenship is significant because some researchers suggest that youth are fully engaged but in less traditional modes (Dalton, 2008; Martin, 2012), while others argue for the inherent value of traditional norms of political participation (Milner, 2010). Before this debate can progress, it is important to establish exactly how students do characterize their civic selves. Finally, due to a lack of empirical research targeting the specific relationships between local, national, and global affiliations, other prompts 
- such as the open-ended questions on national and global citizenship - were developed specifically for this inquiry.

The sampled students $(n=64)$ were domestic and international upper secondary students aged 16-18 in Victoria, B.C., enrolled in a course with a significant citizenship mandate (Social Studies 11 or alternative programs designed to incorporate these credits). This group of students is of interest because they are meant to experience major lessons in citizenship and are on the cusp of reaching the legal voting age in Canada. In a study concerned with the construction of subjectivity, demographics related to place and experiences were of particular note.

Despite the inclusion of a cross-grade class, students were primarily in Grade $11(89 \%)$ between the ages of 14-17, with 95\% falling into the 15-16 age category expected for their grade levels. The alternative civics class was slightly overrepresented (58\%) in the sample. The sample consisted primarily of domestic students, but three long-term and five visiting international students $(12 \%$ of sample) were invited to participate as they have opted into these programs and represent a valuable youth voice in our Canadian classrooms. These students could comment on what they perceived as Canadian values and subjectivities, and were given "N/A" options where prompts questioned personal salience of Canadian identities or cultures. Forty-six percent of students identified as female, none chose "other," and one student skipped the question. A majority of participants were born in Canada, with 53\% being born on Vancouver Island and another 20\% born elsewhere in Canada. Although 52\% reported fluency in two or more languages, English reigned as the primary language spoken at home (77\%), where parents were on the whole more likely to have both been born in Canada (59\%) than both outside of the country $(25 \%)$.

Taken together, a strong majority of the group (81\%) identified themselves as Canadian citizens (including single and dual identifications), and of these most were born in the city of study (62\%). Separated by self-reported citizenships, students showed a variable strength of identification with an assumed culture of the nation. Of those who label themselves Canadianonly citizens $-67 \%$ of total sample $-19 \%$ also felt strongly associated with 'Canadian' as a cultural tag; in contrast, those who reported citizenship from a single other country - notably a mix of domestic and all of the international students $-90 \%$ listed that same nation as a relevant cultural tag. Alternative reported cultures included religious affiliations, ethnic groups not associated with a nation, and nations other than their primary citizenship.

\begin{tabular}{|c|c|c|c|c|c|c|c|c|}
\hline \multicolumn{2}{|c|}{ Reported Citizenship } & $\%$ & \multicolumn{3}{|c|}{ Reported Culture } & $\begin{array}{c}\text { \% Born } \\
\text { Victoria } \\
\text { BC }\end{array}$ & $\begin{array}{l}\text { \% Born } \\
\text { out CAD }\end{array}$ & $\begin{array}{c}\text { \% Caregivers } \\
\text { one or both } \\
\text { born outside } \\
\text { CAD }\end{array}$ \\
\hline Canadian & 43 & 67 & $\begin{array}{l}\text { CAD } \\
\text { ALT } \\
\text { None }\end{array}$ & $\begin{array}{c}8 \\
19 \\
18\end{array}$ & $\begin{array}{l}19 \\
44 \\
42\end{array}$ & 70 & 5 & 21 \\
\hline Canadian Dual & 9 & 14 & $\begin{array}{l}\text { CAD } \\
\text { ALT } \\
\text { None }\end{array}$ & $\begin{array}{l}2 \\
3 \\
4\end{array}$ & $\begin{array}{l}22 \\
33 \\
44\end{array}$ & 22 & 44 & 78 \\
\hline Other & 10 & 16 & $\begin{array}{c}\text { Same } \\
\text { Nation } \\
\text { ALT } \\
\text { None }\end{array}$ & $\begin{array}{l}9 \\
1 \\
1\end{array}$ & $\begin{array}{l}90 \\
10 \\
10\end{array}$ & 0 & 100 & $\begin{array}{c}100 \\
\text { (note: } 1 \text { of } 10 \\
\text { with one parent } \\
\text { born in CAD) }\end{array}$ \\
\hline $\begin{array}{l}\text { Other dual } \\
\text { "Person" }\end{array}$ & $\begin{array}{l}1 \\
1\end{array}$ & $\begin{array}{l}2 \\
2\end{array}$ & & $\begin{array}{l}\text { and a } \\
\text { one }\end{array}$ & & $\begin{array}{c}0 \\
100\end{array}$ & $\begin{array}{c}100 \\
0\end{array}$ & $\begin{array}{l}\text { all in } C A D \\
\text { all in } C A D\end{array}$ \\
\hline
\end{tabular}




\section{Results}

\section{National Citizenship}

Six themes characterized the qualitative responses to "being Canadian means": behaviours (63\%); pride and asserting identity (44\%); state-based responses (41\%); rights, freedoms, and privileges (38\%), values (22\%), and an emphasis on global rather than national $(3 \%)$. To students, being Canadian primarily brought to mind behaviours, including acting with kindness, being tolerant and welcoming, and acting morally. Following this, a loud nationalism ran through slightly under half of the responses in mentions of: having pride, cultural symbols, comparison with America, symbols of the natural world, and knowing history. After pride, responses were next characterized by institutional symbols, noting legal status, noting residency, political symbols, and a sense of duty. Closely related and closely following were mentions of Canadian rights, freedoms, and privileges, and finally, values, including: a shared moral system, environmentalism and the land, multiculturalism, global awareness, and making the world a better place often through taking a political stand. The small but notable feeling that being Canadian means "nothing" because Canadians are global is significant in light of former studies.

\begin{tabular}{|c|c|c|}
\hline \multicolumn{3}{|c|}{ National Citizenship Themes: "In my opinion, being Canadian means..." } \\
\hline & \# & $\%$ \\
\hline \multicolumn{2}{|l|}{ Behaviours } & $63 \%$ \\
\hline Acting with kindness & 18 & \\
\hline Being tolerant and welcoming & 18 & \\
\hline Acting morally & 4 & \\
\hline \multicolumn{2}{|l|}{ Pride and Asserting Identity } & $44 \%$ \\
\hline Having pride & 12 & \\
\hline Cultural symbols & 9 & \\
\hline Comparisons with America & 3 & \\
\hline Symbols of the natural world & 2 & \\
\hline Knowing history & 2 & \\
\hline \multicolumn{2}{|l|}{ State-based Responses } & $41 \%$ \\
\hline Institutional symbols & 12 & \\
\hline Legal status & 5 & \\
\hline Residency & 4 & \\
\hline Political symbols & 3 & \\
\hline A sense of duty to country & 2 & \\
\hline Rights, Freedoms, and Privileges & 24 & $38 \%$ \\
\hline \multicolumn{2}{|l|}{ Values } & $22 \%$ \\
\hline A shared moral system & 4 & \\
\hline Environmentalism and the land & 3 & \\
\hline Multiculturalism & 3 & \\
\hline Global awareness & 3 & \\
\hline
\end{tabular}


Making the world a better place

Nothing 1 2 $3 \%$

Students felt that there is something about Canadians that makes them distinct from other cultures (69\% agree or strongly agree, $17 \%$ neutral). There is a slightly tempered but still strong feeling across the sample that there is some difference between "being Canadian" and "being a Canadian citizen" (50\% agree or strongly agree, $34 \%$ neutral).

\section{Global Citizenship}

Open-ended descriptions of global citizenship emphasized being active (55\%), being aware (41\%), having a sense of belonging (25\%), and being collaborative ( $9 \%)$.

\section{Global Citizenship Themes: "To me, being a global citizen means..." \\ To Be Active}

\begin{tabular}{|c|c|c|c|c|}
\hline & $\begin{array}{c}\text { Active } \\
\text { Make the world better } \\
\text { Care for others } \\
\text { Environmentalism }\end{array}$ & $\begin{array}{l}15 \\
8 \\
6 \\
6\end{array}$ & & \\
\hline To Be Aware & & & 26 & $41 \%$ \\
\hline & $\begin{array}{c}\text { Aware } \\
\text { Open / tolerant / kind } \\
\text { Individual rights / respect } \\
\text { Multicultural }\end{array}$ & $\begin{array}{l}12 \\
9 \\
3 \\
2\end{array}$ & & \\
\hline To Be Collaborative & $\begin{array}{l}\text { Shared values } \\
\text { International collaboration } \\
\text { International governance }\end{array}$ & $\begin{array}{l}4 \\
1 \\
1\end{array}$ & 6 & $9 \%$ \\
\hline To Belong & $\begin{array}{l}\text { To a community } \\
\text { To multiple nations } \\
\text { To the world }\end{array}$ & $\begin{array}{c}4 \\
2 \\
10\end{array}$ & 16 & $25 \%$ \\
\hline
\end{tabular}

Significantly, students felt able to balance multiple subjectivities, generally reporting that being a global citizen is compatible with having a national identity ( $50 \%$ agree, $34 \%$ neutral).

\section{Enacting good citizenship}

In line with results from quantitative Likert items from IEA's ICCS study of 38 countries (Schulz, Ainley, Fraillon, Kerr, \& Losito, 2010), students generally ranked behaviours associated with conventional and social-movement-related citizenships as more important $(52 \%$ and $54 \%$ respectively) than not, with "joining a political party" being the least valued (only 14\% ranking it 
either somewhat or very important) and "voting in every election" being the most valued (75\% somewhat or very important) across the item sets.

\section{Conventional Citizenship Items}

\begin{tabular}{|c|c|c|c|c|c|c|}
\hline & & $\begin{array}{c}1 \text { Not } \\
\text { true/ } \\
\text { important }\end{array}$ & $\begin{array}{c}2 \\
\text { Minimally }\end{array}$ & 3 [not sure] & 4 Somewhat & $\begin{array}{l}5 \text { Very true } / \\
\text { important }\end{array}$ \\
\hline 1 & votes in every election & $\begin{array}{l}1.56 \% \\
\text { (1) }\end{array}$ & $\begin{array}{l}6.25 \% \\
(4)\end{array}$ & $\begin{array}{l}17.19 \% \\
(11)\end{array}$ & $\begin{array}{l}34.38 \% \\
(22)\end{array}$ & $\begin{array}{l}40.63 \% \\
(26)\end{array}$ \\
\hline 2 & joins a political party & $\begin{array}{l}21.88 \% \\
\quad(14)\end{array}$ & $\begin{array}{c}23.44 \% \\
(15)\end{array}$ & $\begin{array}{c}40.63 \% \\
(26)\end{array}$ & $\begin{array}{c}9.38 \% \\
(6)\end{array}$ & $\begin{array}{l}4.69 \% \\
(3)\end{array}$ \\
\hline 3 & $\begin{array}{l}\text { knows about the } \\
\text { country's history }\end{array}$ & $\begin{array}{l}1.56 \% \\
(1)\end{array}$ & $\begin{array}{l}4.69 \% \\
(3)\end{array}$ & $\begin{array}{c}23.4 \% \\
(15)\end{array}$ & $\begin{array}{l}50.00 \% \\
(32)\end{array}$ & $\begin{array}{c}20.31 \% \\
(13)\end{array}$ \\
\hline 4 & $\begin{array}{l}\text { follows political issues } \\
\text { in the newspaper, on the } \\
\text { radio or on TV }\end{array}$ & $\begin{array}{l}3.13 \% \\
(2)\end{array}$ & $\begin{array}{l}15.63 \% \\
(10)\end{array}$ & $\begin{array}{c}25.00 \% \\
(16)\end{array}$ & $\begin{array}{c}39.06 \% \\
(25)\end{array}$ & $\begin{array}{c}17.19 \% \\
(11)\end{array}$ \\
\hline 5 & $\begin{array}{c}\text { shows respect for } \\
\text { government } \\
\text { representatives [leaders, } \\
\text { officials] }\end{array}$ & $\begin{array}{l}6.25 \% \\
(4)\end{array}$ & $\begin{array}{l}7.81 \% \\
(5)\end{array}$ & $\begin{array}{c}32.81 \% \\
(21)\end{array}$ & $\begin{array}{c}37.50 \% \\
(24)\end{array}$ & $\begin{array}{c}15.63 \% \\
(10)\end{array}$ \\
\hline 6 & $\begin{array}{l}\text { engages in political } \\
\text { discussions }\end{array}$ & $\begin{array}{l}3.13 \% \\
(2)\end{array}$ & $\begin{array}{c}18.75 \% \\
(12)\end{array}$ & $\begin{array}{l}32.81 \% \\
(21)\end{array}$ & $\begin{array}{c}34.38 \% \\
(22)\end{array}$ & $\begin{array}{c}10.94 \% \\
(7)\end{array}$ \\
\hline & Averages & \multicolumn{2}{|c|}{$19.01 \%$} & $28.65 \%$ & \multicolumn{2}{|c|}{$52.35 \%$} \\
\hline
\end{tabular}

\section{Social-Movement Related Citizenship Items}

\begin{tabular}{|c|c|c|c|c|c|c|}
\hline & & $\begin{array}{c}1 \text { Not } \\
\text { true/ } \\
\text { important }\end{array}$ & $\begin{array}{c}2 \\
\text { Minimally }\end{array}$ & 3 [not sure] & 4 Somewhat & $\begin{array}{l}5 \text { Very true } \\
\text { important }\end{array}$ \\
\hline 1 & $\begin{array}{c}\text { would participate in a } \\
\text { peaceful protest against } \\
\text { a law believed to be } \\
\text { unjust }\end{array}$ & $\begin{array}{l}9.52 \% \\
(6)\end{array}$ & $\begin{array}{l}11.11 \% \\
(7)\end{array}$ & $\begin{array}{l}34.92 \% \\
(22)\end{array}$ & $\begin{array}{l}33.33 \% \\
(21)\end{array}$ & $\begin{array}{l}11.11 \% \\
(7)\end{array}$ \\
\hline 2 & $\begin{array}{l}\text { participates in activities } \\
\text { to benefit people in the } \\
\text { community [society] }\end{array}$ & $\begin{array}{l}4.69 \% \\
(3)\end{array}$ & $\begin{array}{l}6.25 \% \\
(4)\end{array}$ & $\begin{array}{l}26.56 \% \\
\quad(17)\end{array}$ & $\begin{array}{l}48.44 \% \\
\quad(31)\end{array}$ & $\begin{array}{l}14.06 \% \\
(9)\end{array}$ \\
\hline 3 & $\begin{array}{l}\text { takes part in activities } \\
\text { promoting human rights }\end{array}$ & $\begin{array}{l}3.13 \% \\
(2)\end{array}$ & $\begin{array}{l}15.63 \% \\
(10)\end{array}$ & $\begin{array}{l}32.81 \% \\
\quad(21)\end{array}$ & $\begin{array}{l}32.81 \% \\
(21)\end{array}$ & $\begin{array}{l}15.63 \% \\
(10)\end{array}$ \\
\hline 4 & $\begin{array}{l}\text { takes part in activities to } \\
\text { protect the environment }\end{array}$ & $\begin{array}{l}3.13 \% \\
(2)\end{array}$ & $\begin{array}{l}6.25 \% \\
(4)\end{array}$ & $\begin{array}{l}31.25 \% \\
(20)\end{array}$ & $\begin{array}{l}42.19 \% \\
(27)\end{array}$ & $\begin{array}{l}17.19 \% \\
(11)\end{array}$ \\
\hline & Averages & \multicolumn{2}{|c|}{$14.93 \%$} & $31.39 \%$ & \multicolumn{2}{|c|}{$53.69 \%$} \\
\hline
\end{tabular}

Items related to more globally-relevant conceptions of responsibility demonstrated a more mixed response. In particular, conflict between global ethics and national law posed a challenge to student value systems. 
Globalized Responsibility Items

\begin{tabular}{|c|c|c|c|c|c|c|}
\hline & & $\begin{array}{c}1 \text { Not } \\
\text { true/ } \\
\text { important }\end{array}$ & $\begin{array}{c}2 \\
\text { Minimally }\end{array}$ & 3 [not sure] & 4 Somewhat & $\begin{array}{l}5 \text { Very true / } \\
\text { important }\end{array}$ \\
\hline 1 & $\begin{array}{l}\text { lives according to a } \\
\text { global code of ethics, } \\
\text { even when this } \\
\text { contradicts the laws in } \\
\text { his or her country of } \\
\text { residence }\end{array}$ & $\begin{array}{l}1.59 \% \\
(1)\end{array}$ & $\begin{array}{c}17.46 \% \\
(11)\end{array}$ & $\begin{array}{l}42.86 \% \\
(27)\end{array}$ & $\begin{array}{l}22.22 \% \\
(14)\end{array}$ & $\begin{array}{l}15.87 \% \\
(10)\end{array}$ \\
\hline 2 & $\begin{array}{c}\text { obeys the laws of } \\
\text { whichever country they } \\
\text { live in, regardless of } \\
\text { personal beliefs }\end{array}$ & $\begin{array}{l}3.13 \% \\
\quad(2)\end{array}$ & $\begin{array}{c}14.06 \% \\
(9)\end{array}$ & $\begin{array}{l}21.88 \% \\
(14)\end{array}$ & $\begin{array}{l}43.75 \% \\
\quad(28)\end{array}$ & $\begin{array}{c}17.19 \% \\
(11)\end{array}$ \\
\hline 3 & $\begin{array}{l}\text { would be willing to } \\
\text { ignore a law that } \\
\text { violated human rights }\end{array}$ & $\begin{array}{l}20.63 \% \\
(13)\end{array}$ & $\begin{array}{l}23.81 \% \\
(15)\end{array}$ & $\begin{array}{l}17.46 \% \\
(11)\end{array}$ & $\begin{array}{l}19.05 \% \\
(12)\end{array}$ & $\begin{array}{c}19.05 \% \\
(12)\end{array}$ \\
\hline & Averages & \multicolumn{2}{|c|}{$26.89 \%$} & $27.40 \%$ & \multicolumn{2}{|c|}{$45.71 \%$} \\
\hline
\end{tabular}

\section{The role of educational institutions}

Asked whether it is important to learn "what it means to be a Canadian," students generally felt that this topic held value, with 33\% agreeing strongly, $41 \%$ agreeing, 14\% feeling neutral, $8 \%$ disagreeing, and only 5\% disagreeing strongly.

Those who felt it was not important (12.5\% total) cited individuality, that it is not helpful, and that it doesn't matter or that other things are more important. Those who were neutral (14\% total) expressed that: youth should already know about this topic or that other topics are more important; the importance of personal choice or a feeling that education would have no impact; and that it is best learned outside of the classroom. In responses from students who felt that it is important for youth to learn what it means to be Canadian (73.5\% of total; 47 students, of which 45 commented why), $45 \%$ based their answer on learning about oneself either through the connection between place and identity or the way that learning about history and about others can influence personal growth and values. The importance of pride, unity, respect, or appreciation featured in $23 \%$ of responses, and a sense of awareness or the possibility to change behaviours underpinned $17 \%$ each.

\section{Knowledge and actions}

Students generally feel confident in their understanding of how federal (94\%), provincial $(80 \%)$, and municipal (83\%) political systems work, with only $5 \%$ of respondents claiming not to know how any of the above function. They report similarly high levels of intent to vote in municipal (73\%), provincial (83\%) and federal (94\%) elections when eligible, with only 5\% responding that they would vote in none of the above. Of the three students in the latter category, the reasons given were current age, not being Canadian, and finally a statement of independence and cynicism regarding the honesty of politicians. Students feel an equally strong responsibility to address political, social, or environmental issues in their local $(59 \%)$, national $(55 \%)$, and 
international communities (51\%), with approximately $20 \%$ feeling minimal or no responsibility across the same categories. This sense of responsibility is also evident in the self-reports of strong engagement thus far in their lives, with a mix of activities from social activism (volunteer in community, $87 \%$; use social media to raise awareness for a cause, $45 \%$ ) to more politicallybased engagement (researched political parties and candidates 77\%; participated in face-to-face discussion or debate about political topics, $52 \%$; voted in an election of any kind, 47\%).

\section{Discussion}

\section{National citizenship, global citizenship, and conflicted narratives}

What does the term citizen actually entail, and what vocabularies do young Canadians use to construct their civic subjectivities? When asked about their citizenship without preamble, that students in this sample generally self-identified with one nation (83\%; none skipped), suggests a more tethered formal identification process than some post-national cosmopolitan theorists might suspect. However, if asked about culture, the answers became much more difficult and diverse: 20\% listed two or more responses, 39\% skipped or answered "none/non-applicable," and only $19 \%$ of self-identified Canadian citizens also felt associated with a "Canadian" culture. The diverse range of responses to the culture prompt - including atheism, anarchism, life, nature, and "white" - suggest that young people feel more room for creativity and self-expression in the undefined space of culture, whereas the term citizenship denotes a more rigid labeling system. Most blatantly, when asked directly, students do feel that Canadians form a distinct group on the world cultural stage and that "being Canadian" is different from the legal or technical status of Canadian citizenship. This raises the question of whether citizenship should be defined for curricular purposes, or explored with the same sense of creative curiosity and openness to perspective as cultural ways of knowing the self.

This is not to say, however, that the nation holds no weight in shaping student subjectivities. Although a common criticism runs, "[m]odern multicultural Canada is no more sure of its role in the world than it is of its identity" (Bliss, 2005, p 5), recent scholarship - and indeed the evidence above - emphasizes a need to reexamine the assumption that youth or Canadians outside Quebec have no shared sense of national identity. On the whole, Canadianborn students identify themselves as Canadian citizens, describe their citizenship in terms of behaviours and values in statements often marked by loud nationalism, value both Conventional and Social-Movement-Related forms of action, and feel that it is important to learn about being Canadian. That there is the greatest range in Conventional Citizenship items (between 14-75\% somewhat/very important rankings) - while Social-Movement-Related items are generally between $30-40 \%$ ranked as important - suggests a greater tension or confusion around the desirability of conventionally accepted citizenship behaviours.

With a similar focus on vocabularies of citizenship, Hildebrand's (2007) interview-based inquiry into what "being" Canadian means to youth revealed 9 themes: the three most common themes spoke to negation and plurality (Being Canadian means nothing much; being multicultural; being un-American), then, in order of frequency, emotions, values, and privileges (being peaceful and safe, being proud, being free, involves symbolism, having democratic rights, being fortunate). While Hildebrand reported that, for young Calgarians, being Canadian means primarily "nothing much" $(60 \%)$ followed most closely by "being multicultural" (43\%), the current findings show only $3 \%$ of the sample disregard national citizenship, and this because of a greater attachment to a globalized subjectivity. More consistent with the current findings, 
Levesque's (2003) study found Canadian youth to be patriotic, multicultural, and globallyminded, but with different experiences having brought them to these "big three" characteristics. (Incidentally, that these three core themes also characterized results of Myers \& Zaman's (2009) results in American youth provides evidence that globalized young adult experiences and values may be more similar across borders than between generations.) Based on the strong national identity responses, Lee and Hébert (2006) argue that "in practice, a diversity of ethnocultural identities does not necessarily diminish association with the national identity in Canada" ( $p$. 517).

In recent years, rooted cosmopolitanism has gained momentum in scholarship on citizenship based on its ability to explain the interplay between global and particular duties, especially in post-colonial and arguably post-national mosaic cultures such as Canada (Kymlicka \& Walker, 2012). The behavioural and attitudinal factors emphasized in descriptions of global citizens, versus the sense of self-definition and identity woven through national citizenship themes suggest that global citizenship is associated more with altruistic reactions to the world, whereas national citizenship provides a framework from which youth position themselves in relation to the world. Both are primarily frameworks through which young people describe the importance of pro-social behaviours: active ways of engaging with and respecting others in community-building and values-enacting. The nationalism reported through this sample seems to provide a sense of "where I come from," while narratives of global citizenship are used to explain questions of "how I engage with." This is in line with other studies that suggest that global citizenship is primarily "a moral commitment framed in universal language" (Myers, 2010, p. 497).

Contrary to propositions that globalization has made national attachments irrelevant to youth, Levesque (2003) found that students express patriotic - though sometimes ahistoric collective identities in addition to strong attachments to the ideal of multicultural society. Moving south, Myers and Zaman's (2009) mixed methods investigation in America placed student beliefs in three categories: post-national citizenship ( 9 students), cosmopolitan patriotism (rooted cosmopolitanism; 9 students), and liberal nationalism (2 students). In interviews, a greater number of students from immigrant backgrounds than students from the dominant culture ascribed to a post-national view of citizenship, while the exact opposite ratio was evident in the rooted cosmopolitan category; dominant culture students in the rooted-cosmopolitan category "expressed concern that global and national citizenship are at odds" and "fear that the universal nature of global citizenship requires conformity to a totalizing set of values and beliefs" and, therefore, described their own subjectivities with vocabulary that avoided conflict between universal responsibilities and their attachment to national citizenship (p. 2611).

Although a large-scale survey of West Coast Canadians suggests that the general public identifies more strongly with geographic - especially national - identities than with personal identities (age, religion, ethnicity), studies of North American youth point to ambivalent and still-evolving constructions, which are no less strongly held (Berdahl, 2006; Hildebrand, 2007; Myers \& Zaman, 2009). In the current study, responses were characterized both by passion and by critical thought: "Students should learn this, but should also understand that citizenship does not define you as a person. Making a big deal out of being Canadian creates unrest in students who don't feel particularly patriotic, and may make them feel like less of a person." Rather than a conflicted sense of the metanarratives shaping their civic subjectivities, it seems evident that students have an increasingly nuanced sense of how to interact with multiple levels of self in their globalized world.

Journal of Contemporary Issues in Education, 2017, 12(1), pp. 32-52. 
Good citizenship and the school's role in educating modern citizens

What does it mean to be a good citizen in a particular context and what role might the school play? Despite the flurry of research in the 1980s and 1990s, "we have very little information on what is actually going on in classrooms, or on how students or teachers see things" (Osborne, 1995, p. 27). A few notable exceptions point to important currents in youth understandings of participation, identity, and belonging, and in students' negotiations between national and global narratives of citizenship (Giron, 2012; Hildebrand, 2007; Levesque, 2003; Lee \& Hébert, 2006; Myers \& Zaman, 2009). Generally, research holds that students hold active citizenship in high regard, use a vocabulary of rights and freedoms to describe their civic subjectivities, and work to negotiate between strongly held national patriotism and attachment to globalized value systems.

This study probed the salience of national sentiment by asking whether "what it means to be Canadian" should be taught in schools and inviting open-ended explanations for each response. For those who felt that learning what it means to be Canadian is not important, individuality was the strongest theme, featuring in over a third of negative responses:

“... [besides] Canada is an immigrant's country, it don't really have a meaning of 'what it means to be Canadian' cause every one's answer are different" [sic]. Essentially these students didn't see the point of teaching the topic. Similarly, those who selected "neutral" felt that being Canadian is frankly not a useful area of study for the classroom: "If we really need to know what it means to be Canadian in my everyday life, [I] will learn it on my own when the time comes. $[\mathrm{O}]$ therwise, there are other things that could be viewed as more important to learn in school."

The majority, however, spoke passionately about the links they perceived between learning about being a Canadian and issues of community membership at national and global scales, pride and respect, and behaviours that promote unity and proactive community improvement. These students argued that

It is important to teach youth about what it means to be Canadian because it is not thought about often and it is crucial to understand what it means to be a part of a community and be part of a country.

and that

[Youth] will eventually grow up and they need to know what [it's] kind of like out there people-wise... there's more than just themselves and I don't think the majority can really appreciate how insignificant they really are and give yourself to something, to make a change.

These and other student responses focused on action, especially in national awareness as a path to personal growth and social justice.

Similarly, Levesque (2003) found that students in Quebec and British Columbia each accord importance to the responsibility of active citizenship, with a similar "rights-based consciousness" and a vocabulary of citizenship revolving around rights, freedoms, and opportunities. A majority emphasized both voting and caring for their communities as their own salient responsibilities, while a minority felt cynical about Canadian politicians and institutions a position the author noted seemed to be associated with "a relatively narrow and limited understanding of democracy, reducing everything to 'elections' and 'referenda"' (Levesque, 2003 , p. 114). The preliminary results of this study lend support to these findings in that an overwhelming majority of students reported an intent to vote when they come of age, with one of three negative responses citing a strong cynicism about the efficiency ("If I want something done Journal of Contemporary Issues in Education, 2017, 12(1), pp. 32-52. 
I will do it myself") and honesty of the political system ("Politicians lie, and I couldn't care less for them keeping their high wages").

Rather than conflicted trans-national selves, then, research tends to reveal students with strong civic subjectivities and a desire to pursue active and socially-responsible forms of citizenship. Perhaps the strongest argument for conflict between national and global metanarratives comes not from the formation of subjectivities, but the potential conflict between global ethics and national law; the uncertainty that characterized responses to globalized responsibility items suggests that schools might play a role less in sorting out belonging and more in how to actually enact values associated with good citizenship. The question of action becomes key to classrooms.

Contrary to students' very active and behaviourally-based definitions of national and global citizenship, Fournier-Sylvester's (2014) study of recent graduates found that courses were content-driven, passive, and using a "liberal democratic perspective that fail[ed] to address inequalities or inspire commitments to political participation or social justice" (p. 17). In the face of a strong body of research supporting active classes and brave conversations on controversial topics (Hughes, Peck, \& Herriot, 2014), this study reveals a disjuncture between effective teaching practices for civic engagement and what student perceive is happening in their classrooms. In Fournier-Sylvester's study, the most consistent suggestion was to make citizenship education a separate class.

\section{Limitations: Current Research and Current Policy}

This paper presents only the first results based on the first wave of data collection in one portion of a larger multiple-case studies design. As a descriptive case study, the results are not generalizable; however, the data have allowed comment on rooted cosmopolitanism as a means of describing youth conception of civic subjectivity. Further, this first analysis is of the full group, not taking into account possible within-group differences between international and domestic student status. It thus represents a good picture of our Canadian classrooms, but may not be as accurate in representing only Canadian students in Canadian classrooms. The full study of amalgamated student bodies across bounded communities, in contrast, will compare three sites as separate case studies and will allow for a more in-depth analysis of the framework of rooted cosmopolitanism.

More importantly, while this paper represents a small portion of the larger project, the full study will address students' classroom experiences with an emphasis on the student voice in recommending policy changes. McCowan's $(2008 ; 2009)$ theory of curricular transposition, focuses attention on disjunctures between the theorizing of ideal persons / societies, curricular program development, implementations of curriculum, and effects on students. In this model, the ideal end is envisioned by adult policy-makers and then embodied in a curricular program; this program is then implemented by administrators and teachers, which has various effects on students. At each juncture is the possibility for mediating variables, so that the final experiences of students and resultant effects may not resemble the original ideal. Given the gap between Canadian rhetoric - from university ideals (Philpott \& Dagenais, 2011, p 96) to trends in political commitment (Hughes \& Sears, 2006) to curricular development (Richardson \& Abbott, 2009) - and the reality suggested by systemic reviews and youth political engagement, the full project will seek to shed light on possible disjunctures between administrative trends and practical implication. Researchers acknowledge that students live and learn in settings shaped by

Journal of Contemporary Issues in Education, 2017, 12(1), pp. 32-52. 
adult expectations of adolescents and that their general exclusion from policy development violates Article 12 of the United Nations Declaration on the Rights of the Child: "Children have the right to say what they think should happen when adults are making decisions that affect them, and to have their opinions taken into account" (Barber, Torney-Purta, Wilkenfeld, \& Ross, 2015, p 27; Sears, Peck, \& Heriot, 2014, p 8). By investigating student perceptions of their own and ideal citizenship, as well as opportunities for civic skills development, this research will suggest a necessary and missing piece of McCowan's model: that of the student voice impacting the imagined ideal citizen and society. In doing so, this work will provide evidence of how student voices are currently incorporated, and will point to areas for future research on active citizenship and participatory niches for adolescents' emergent citizenship (Bron \& Veugelers, 2014; Torney-Purta \& Amadeo, 2011).

\section{Conclusion}

The current project was born of observing inspired teachers. These teachers sought to address ambitious and relevant questions in their classroom: What does it mean to be a Canadian, and what is Canada's responsibility to the world? Evident in these questions are the points of tension in any citizenship education program: they hope to address legal and social belonging in a highly diverse population, to reconcile the right to personally-held values with ethical obligations that unify on a global or national scale, and to bring attitudes and actions into the light so that students may be empowered in their own sense of civic subjectivity.

The larger study of which this data is a part, strives to shed light on how student vocabularies of citizenship are subjectively constructed and salient, but also contingent on context. The data presented here investigates the foundation: what vocabularies of citizenship students use to describe their sense of national and global citizenship, and whether there is an acknowledged conflict between these levels. The data reveals a relatively engaged, thoughtful, and patriotic picture of Canadian youth on the West coast of Canada; a group that holds both national and global citizenship conceptions in mind, and that looks to interact with their communities. Lee and Hébert (2006) point hopefully to the fluidity and strategic nature of group and national identities as potential patterns for reducing social tension: "It will become increasingly difficult to categorize 'others' and locate them along racialized fault lines in Canadian society... Whether the youth are in Calgary, British Columbia, or Quebec, they are all children of multiculturalism" (pp. 514-515).

Educators have a responsibility to make "a conscious effort to help adolescents build flexible and multiple civic identities," using curricula that open spaces for students to see past simple national-global binaries and instead to recognize their diverse roles in the world and make connections between their lived experiences and the school curriculum (Myers \& Zaman, 2009). The current project addresses calls for work "that digs beneath nationalist mythology" with attention to the ways salience and affective impact of one's national identity conditions its consequences (Raney, 2010, p 119; Reeskens \& Wright, 2013, p. 171). This study looked to describe student vocabularies but also to provide students with a valuable platform for communicating with the research and education communities: the questionnaire gave students an opportunity to voice their feeling about whether it is important or appropriate for the concept of "Canadian" to be addressed in schools. Overwhelmingly, students rated learning about being Canadian as important, and were able to articulate powerful reasons why. Those who disagreed, however, had thoughtful responses that spoke to a serious consideration of their civic 
subjectivities. Furthermore, the group expressed a sense of responsibility to communities at all levels and strong confidence in their knowledge of and intention to participate in federal, provincial, and municipal voting. These positive results should encourage adult communities to question the common narrative about youth apathy and instead to consider the experiences or systems that may keep a motivated and emotionally invested generation from participating as they intend.

This study and its larger counterpart hope to contribute to the uniquely Canadian conversation regarding pedagogy and citizenship, a conversation that too often is dominated by abstract theoretical discussions and European data. Hughes, Print, and Sears (2010) argue that "the research base for citizenship education [in Canada] is weak and fragmented" (p. 305), noting that comparative studies reveal "countries where national debate about citizenship and citizenship education was encouraged and conducted were more likely to produce substantial and widely implemented programs in the area" (p. 297). Civics and Social Studies classrooms aim to encourage young people to participate in national debate, but the adult world needs to make space for the student voice in meaningful ways through research and through policy development. The Canadian perspective will be critical to the future of citizenship education in this nation and abroad; the student voice must be heard in the conversation. 


\section{References}

Anderson, C., \& Goodyear-Grant, E. (2008). Youth turnout: Adolescents' attitudes in Ontario. Canadian Journal of Political Science, 41(3), 697-718. http://dx.doi.org/10.1017/S0008423908080773

Andolina, M., Jenkins, K., Zukin, C., \& Keeter, S. (2003). Habits from home, lessons from school: Influences on youth civic engagement. Political Science and Politics, 36(2), 275280. http://dx.doi.org/10.1017/S104909650300221X

Appiah, K. A. (1996). Cosmopolitan patriots. In J. Cohen (Ed.), For love of country (pp. 21 29). Boston: Beacon Press. http://dx.doi.org/10.1086/448846

Appiah, K. A. (2006). Cosmopolitan: Ethics in a world of strangers. New York: W. W. Norton.

Ariely, G. (2011). Constitutional patriotism, liberal nationalism and membership in the nation: An empirical assessment. Acta Politica, 46(3), 294-319. http://dx.doi.org/10.1057/ap.2011.10

Ashizawa, K. (2008). When identity matters: State identity, regional institution-building, and Japanese foreign policy. International Studies Review, 10(3), 571-598.

http://dx.doi.org/10.1111/j.1468-2486.2008.00805.x

Barber, C., Torney-Purta, J., Wilkenfeld, B., \& Ross, J. (2015). Immigrant and native-born adolescents' civic knowledge and attitudes in Sweden and the United States: Emergent citizenship within developmental niches. Research In Comparative \& International Education, 10(1), 23-47. http://dx.doi.org/10.1177/1745499914567818

BC Ministry of Education. (2007). Social studies curriculum (grades 8 to 12) needs assessment: Executive summary. https://www.bced.gov.bc.ca/irp/reports/ss8-12_exec_summary.pdf

Benjamin, D., Choi, J., \& Strickland, A. (2010). Social identity and preferences. The American Economic Review, 100(4), 1913-1928. http://dx.doi.org/10.1257/aer.100.4.1913

Berdahl, L., \& Raney, T. (2010). Being Canadian in the world. International Journal: Canada's Journal of Global Policy Analysis, 65(4), 995-1010. http://dx.doi.org/10.1177/002070201006500424

Berdahl, L. (2006). Political identities in Western Canada: An analysis of the Looking West 2006 Survey. Canada West Foundation.

Blake, R. B. (2013). A new Canadian dynamism. British Journal of Canadian Studies, 26(1), 79104.

Bliss, M. (2005). Has Canada failed? Literary Review of Canada, 14(2), 3-5.

Bron, J., \& Veugelers, W. (2014). Why we need to involve our students in curriculum design: Five arguments for student voice. Curriculum and Teaching Dialogue, 16(1-2), 125-140.

Brysk, A. (2009). Global good samaritans: Human rights as foreign policy. New York: Oxford University Press. http://dx.doi.org/10.1093/acprof:oso/9780195381573.001.0001

Caron, J. (2012). Rooted cosmopolitanism in Canada and Quebec. National Identities, 14(4), 351 -366. http://dx.doi.org/10.1080/14608944.2011.616954

Carter, M. (2013). Advancing identity theory: Examining the relationship between activated identities and behaviour in different social contexts. Social Psychology Quarterly, 76(3), 203 - 223. http://dx.doi.org/10.1177/0190272513493095

Charnysh, V., Lucas, C., \& Singh, P. (2015). The ties that bind: National identity salience and pro-social behaviour toward the ethnic other. Comparative Political Studies, 48(3), 267 300. http://dx.doi.org/10.1177/0010414014543103 
Chen, Y., \& Li, S. (2009). Group identity and social preferences. The American Economic Review, 99(1), 431-457. http://dx.doi.org/10.1257/aer.99.1.431

Dalton, R. (2008). Citizenship norms and the expansion of political participation. Political Studies, 56, 76-98. http://dx.doi.org/10.1111/j.1467-9248.2007.00718.x

Dittmer, J., \& Larsen, S. (2007). Captain Canuck, audience response, and the project of Canadian nationalism. Social \& Cultural Geography, 8(5), 735-753.

http://dx.doi.org/10.1080/14649360701633311

Evans, M. (2003). Education for citizenship in schools in Canada. Orbit, 33(2), 33-37.

Fafard, P., Rocher, F., \& Cote, C. (2010). The presence (or lack thereof) of a federal culture in Canada: The views of Canadians. Regional and Federal Studies, 20(1), 19-43. http://dx.doi.org/10.1080/13597560903174873

Fournier-Sylvester, N. (2014). A/political education: A survey of Quebec students' perceptions of their citizenship education. Canadian Journal of Education, 37(3), 1-23.

Gagnon, F., \& Pagé, M. (1999). Conceptual framework and analysis: Volume 1 of Conceptual framework for an analysis of citizenship in the liberal democracies. Ottawa: Canadian Heritage. Retrieved from http://citeseerx.ist.psu.edu/viewdoc/download?doi=10.1.1.575.8298\&rep=rep1\&type=pdf

Giron, L. A. M. (2012). Educating good citizens: A case study of citizenship education in four multicultural high school classrooms in Ontario. Doctoral dissertation. Ottawa: University of Ottawa. Retrieved from https://www.ruor.uottawa.ca/bitstream/10393/20713/1/Molina_Giron_Luz_Alison_thesis_ 2012.pdf

Glassford, L. (2010). Citizenship literacy and national self-identity: The historical impact of curriculum and textbooks in shaping the character of Ontario. Active History.ca. Retrieved from http://activehistory.ca/papers/history-paper-5/\#1

Hepburn, E. (2011). 'Citizens of the region': Party conceptions of regional citizenship and immigrant integration. European Journal of Political Research, 50, 504-529. http://dx.doi.org/10.1111/j.1475-6765.2010.01940.x

Hildebrand, L. J. (2007). Canadian cosmopolitanism: Youth perspectives of citizenship for the postmodern era. Masters dissertation. University of Calgary. Retrieved from Library and Archives Canada (978-0-494-34026-4).

Ho, L., \& Baildon, M. (2013). Geographies of online spaces and intercultural citizenship. Intercultural Education, 24(4), 327-340. http://dx.doi.org/10.1080/14675986.2013.809246

Hodgetts, A. B. (1968). What culture? What heritage? A study of civic education in Canada. Toronto: OISE Press.

Hooghe, M., \& Quintelier, E. (2013). Do all associations lead to lower levels of ethnocentrism? A two-year longitudinal test of the selection and adaptation model. Political Behaviour, 35, 289-309. http://dx.doi.org/10.1007/s11109-012-9201-5

Howe, P. (2010). Citizens adrift: The democratic disengagement of young Canadians. Vancouver: UBC Press.

Hughes, A., \& Sears, A. (2006). Citizenship education: Canada dabbles while the world plays on. Education Canada, 46(4), 6-9.

Hughes, A., Print, M., \& Sears, A. (2010). Curriculum capacity and citizenship education: A comparative analysis of four democracies. Compare: A Journal of Comparative and International Education, 40(3), 293-309. http://dx.doi.org/10.1080/03057920903395528 
Hughes, S., Peck, C., \& Herriot, L. (2014). We're here to teach about democracy not practice it. The missed potential of schools as democratic spaces. One World in Dialogue, 3(1).

Isac, M., Maslowski, R., Creemers, B., \& van der Werf, G. (2014). The contribution of schooling to secondary-school students' citizenship outcomes across countries. School Effectiveness and School Improvement, 25(1), 29-63. http://dx.doi.org/10.1080/09243453.2012.751035

Kahne, J., \& Sporte, S. (2008). Developing citizens: The impact of civic learning opportunities on civic participation. American Educational Research Journal, 45(3), 738-766. http://dx.doi.org/10.3102/0002831208316951

Kennelly, J. (2011). Citizen youth: Culture, activism, and agency in a neoliberal era. New York: Palgrave Macmillan. http://dx.doi.org/10.1057/9780230119611

Kennelly, J., \& Llewellyn, K. (2011). Educating for active compliance: Discursive constructions in citizenship education. Citizenship Studies, 15(6-7), 897-914. http://dx.doi.org/10.1080/13621025.2011.600103Kymlicka, W., \& Walker, K. (2012). Introduction. In W. Kymlicka \& K. Walker (Eds.), Rooted cosmopolitanism: Canada and the world (pp. 1-30). Vancouver: UBC Press.

Leinweber, K., Donlevy, J., Gereluk, D., Patterson, P., \& Brar, J. (2012). Moral education policies in five Canadian provinces: Seeking clarity, consistency, and coherency. Interchange, 43, 25-42.

Lee, W., \& Hébert, Y. (2006). The meaning of being Canadian: A comparison between youth of immigrant and non-immigrant origins. Canadian Journal of Education, 29(2), 497-520. http://dx.doi.org/10.2307/20054174

Lenard, P. T., \& Moore, M. (2012). A defense of moderate cosmopolitanism and/or moderate literal nationalism. In W. Kymlicka, \& K. Walker (Eds.). Rooted cosmopolitanism: Canada and the world (pp. 47-68). Vancouver: UBC Press.

Levesque, S. (2003). Becoming citizens: High school students and citizenship in British Columbia and Quebec. Encounters on Education, 4, 107-126. http://dx.doi.org/10.15572/ENCO2003.06

Lewis, J. (2011). The unavoidable struggle of Canadian citizenship education: An analysis of historical and contemporary challenges of producing a cohesive policy narrative. Doctoral dissertation. Ottawa: Carleton University.

Macintyre, S., \& Simpson, N. (2009). Consensus and division in Australian citizenship education. Citizenship Studies, 13(2), 121-134. http://dx.doi.org/10.1080/13621020902731132

Martin, A. (2012). Political participation among the young in Australia: Testing Dalton's good citizen thesis. Australian Journal of Political Science, 47(2), 211-226. http://dx.doi.org/10.1080/10361146.2012.677003

McCowan, T. (2008). Curricular transposition in citizenship education. Theory and Research in Education, 6(2), 153-172. http://dx.doi.org/10.1177/1477878508091109

McCowan, T. (2009). Rethinking citizenship education: A curriculum for participatory democracy. London: Continuum.

McCowan, T. (2010). School democratization in prefigurative form: Two Brazilian experiences. Education, Citizenship, and Social Justice, 5, 21-41. http://dx.doi.org/10.1177/1746197909353567

McGrane, D., \& Berdahl, L. (2013). 'Small worlds' no more: Reconsidering provincial political cultures in Canada. Regional \& Federal Studies, 23(4), 479-493.

http://dx.doi.org/10.1080/13597566.2013.794415

Journal of Contemporary Issues in Education, 2017, 12(1), pp. 32-52. 
McKenzie, H. (1993). Citizenship education in Canada. Research Branch, Library of Parliament. Retrieved from http://www.lop.parl.gc.ca/Content/LOP/ResearchPublicationsArchive/bp1000/bp326-e.asp

Mellor, S., Kennedy, K., \& Greenwood, L. (2002). Citizenship and democracy: Australian students' knowledge and beliefs: The IEA civic education study of fourteen year olds. Victoria: Australian Council for Educational Research. http://dx.doi.org/10.1017/CBO9780511814266.012

Milner, H. (2010). The internet generation: Engaged citizens or political dropouts. Lebanon NH: Tufts University Press.

Mitchell, K. (2003). Educating the national citizen in neoliberal times: From the multicultural self to the strategic cosmopolitan. Transactions of the Institute of British Geographers, 28(4), 387-403. http://dx.doi.org/10.1111/j.0020-2754.2003.00100.x

Myers, J., \& Zaman, H. (2009). Negotiating the global and national: Immigrant and dominant culture adolescents' vocabularies of citizenship in a transnational world. Teachers College Record, 111(11), 2589-2625.

Myers, J. (2010). 'To benefit the world by whatever means possible': Adolescents' constructed meanings for global citizenship. British Educational Research Journal, 36(3), 483 - 502. http://dx.doi.org/10.1080/01411920902989219

Nimijean, R. (2005). Articulating the 'Canadian Way': Canada ${ }^{\mathrm{TM}}$ and the political manipulation of the Canadian identity. British Journal of Canadian Studies, 18(1), $26-52$. http://dx.doi.org/10.3828/bjcs.18.1.2

Osborne, K. (1995). In defense of history: Teaching the past and the meaning of democratic citizenship. Toronto: Our Schools/Ourselves Educational Foundation.

Osborne, K. (1996). Education is the best national insurance: Citizenship education in Canadian schools, past and present. Canadian and International Education, 25(2) 33-58.

Osborne, K. (2003). Teaching history in schools: A Canadian debate. Journal of Curriculum Studies, 35(5), 585-626. http://dx.doi.org/10.1080/0022027032000063544

Parkin, A., \& Mendelsohn, M. (2003). A new Canada: An identity shaped by diversity. Paper 11. Ottawa, ON: Centre for Research and Information on Canada.

Pashby, K., Ingram, L., \& Joshee, R. (2014). Discovering, recovering, and covering up Canada: Tracing historical citizenship discourses in K-12 and adult immigrant citizenship education. Canadian Journal of Education, 37(2), 1-26.

Philpott, R., \& Dagenais, D. (2011). Grappling with social justice: Exploring new teachers' practice and experiences. Education, Citizenship, and Social Justice, 7(1), 85-99. http://dx.doi.org/10.1177/1746197911432590

Quintelier, E. (2015). Engaging adolescents in politics: The longitudinal effect of political socialization agents. Youth \& Society, 47(1), 51-69. http://dx.doi.org/10.1177/0044118X13507295

Raney, T. (2010). Quintessentially un-American? Comparing public opinion on national identity in English speaking Canada and the United States. International Journal of Canadian Studies, 42, 105-123. http://dx.doi.org/10.7202/1002174ar

Raney, T., \& Berdahl, L. (2009). Birds of a feather? Citizenship norms, group identity, and political participation in Western Canada. Canadian Journal of Political Science, 42(1), 187-209. http://dx.doi.org/10.1017/S0008423909090076

Journal of Contemporary Issues in Education, 2017, 12(1), pp. 32-52. 
Raney, T., \& Berdahl, L. (2011). Shifting sands? Citizens' national identities and pride in social security in Canada. American Review of Canadian Studies, 41(3), 259-273. http://dx.doi.org/10.1080/02722011.2011.594521

Reeskens, T., \& Wright, M. (2013). Nationalist and the cohesive society: A multilevel analysis of the interplay among diversity, national identity, and social capital across 27 European societies. Comparative Political Studies, 46(2), 153-181.

Richardson, G., \& Abbott, L. (2009). Between the national and the global: Exploring tensions in Canadian citizenship education. Studies in Ethnicity and Nationalism, 9(3), 33-394. http://dx.doi.org/10.1111/j.1754-9469.2009.01059.x

Schulz, W., Ainley, J., Fraillon, J., Kerr, D., \& Losito, B. (2010). ICC 2009 international report: Civic knowledge, attitudes, and engagement among lower-secondary school students in 38 countries. Amsterdam: International Association for the Evaluation of Educational Achievement.

Sears, A. M., Clarke, G. M., \& Hughes, A. S. (1999). Canadian citizenship education: The pluralist ideal and citizenship education for a post-modern state. In J. Torney-Purta, J. Schwille, \& J. Amadeo (Eds.). Civic education across countries: Twenty-four national case studies from the IEA Civic Education Project. Amsterdam: International Association for the Evaluation of Educational Achievement.

Sears, A., Peck, C., \& Herriot, L. (2014). We're here to teach about democracy not practice it. The missed potential of schools as democratic spaces. One World in Dialogue, 3(1).

Tajfel, H., \& Turner, J. (1979). An integrative theory of intergroup conflict. In W. G. Austin, \& S. Worchel (Eds.). The social psychology of intergroup relations (pp. 33-47). Salt Lake City: Brooks Cole Publishing.

Tan, K. (2012). Cosmopolitanism and patriotism. In W. Kymlicka, \& K. Walker (Eds.). Rooted cosmopolitanism: Canada and the world (pp. 31-46). Vancouver: UBC Press.

Torney-Purta, J., \& Amadeo, J. (2011). Participatory niches for emergent citizenship in early adolescence: An international perspective. The ANNALS of the American Academy of Political and Social Science, 633(180), 180-200.

http://dx.doi.org/10.1177/0002716210384220 